\title{
2. ON THE EDUCATIONAL POTENTIAL OF FOLK DANCE
}

Petre Şuşu ${ }^{105}$

\begin{abstract}
Folk dance, described in Folkloristics through notions like traditional dance, or, more often, folk choreography, refers to a specific domain of traditional spirituality, and is the third major component of folklore, alongside traditional literature/literary folklore and traditional music/musical folklore.The relation between folk dance and the Romanian education system is a long-lasting one, having taken various forms and degrees of intensity, as this folklore category offers resources and contents that have been used, and still are, in the education of children, youth, and adults. This article refers to the basic components of folk dance distinguished in Ethnochoreology which can offer useful contents to the process of didactic transposition at different levels of education in the Romanian school.
\end{abstract}

Key words: folklore, folk dance, choreographic contents, didactic transposition

\section{Introduction}

Folk dance, also known as traditional dance, ethnic dance, or folk choreography, joins musical folklore and literary folklore to complete the major field of folklore, thus being a distinct third component of this field. Due to the fact that it is a collective creation, folk dance, through syncretic acts developed in the context of dance movement, highlights the common, representative aspects of the character and personality of the individuals from the community in which it appears and develops. Compared to other forms of cultural and artistic manifestation, folk dance is the one that appears most frequently at the level of a community's social life, for which it fulfils certain ceremonial, ritual, or entertainment functions, as a means of communication for the transmission or approval of norms, and for the expression of feelings, states, beliefs, etc. The study of folk dance is the object of the scientific discipline known as Ethnochoreology.

As a recognition of the spiritual and educational values that have been encompassed by folk dance, the Romanian traditional school has given it special attention. Never absent from the program of school festivities, folk dance accompanied the educational reforms made by Spiru Haret through the laws for the organization of secondary and higher education (1898), respectively professional education (1899). Practiced at the gatherings the teachers had the duty to organize through the school institutions, folk dance was also a context for educating the adults. Folk dance's quality of being a bond between the school and the community's social life was thoroughly used in that period, when dancing in the village was "alive" and the Romanian education was just settling on modern principles.

Nowadays, although the contexts of community-organized folk dance have lost a great deal, in terms of frequency, content, and intensity, folk dance is still a frequent activity in Romanian schools. Here, activities that include folk dance

\footnotetext{
${ }^{105}$ Doctoral Candidate, „Alexandru Ioan Cuza” University from Iaşi, Romania, email: petre_susu@yahoo.com
} 
are organized as part of the non-formal education, in both formal education institutions, and non-formal ones (such as children clubs), or as part of the formal education done in interdisciplinary contexts, in integrated forms, or as disciplines in the secondary education choreography institutions, and, sporadically, in higher education choreography (or sports) institutions. An example that might give the measure of the frequency of folk dance activities in primary and secondary education is provided by the results of a study I did in 2013, which surveyed teachers in Iaşi county on the topic of the opportunity of featuring folk dance as a study discipline in primary education; $44,14 \%$ of the interviewed answered affirmatively to the question "do you organize folk dance activities with your students?".

This result shows that, in Iaşi county, there are at least 2500 teachers that organize folk dance activities with primary education students. Based on the experience I have acquired in over 20 years of educational and artistic activity in the field of folk dance, I believe that the aforementioned number may be considered representative for any of the large counties in Romania. Back to the study I have previously mentioned, the respondents' motivation was argued by their intention to satisfy some of the educational needs of knowing the culturaltraditional heritage and value, needs that have a permanent character in the context of the educational partnership school - family - community. However, this study also showed that, in most cases, the objectives of the educational activities that include folk dance and that are coordinated by teachers aim at creating performances, the artistic (and, implicitly, educational) value of which greatly depends on the spare time the teachers and the students have at their disposal, but especially on the knowledges, abilities, and skills in the field of folk choreography the teacher has.

But, given the fact that primary education teachers in the Romanian school system do not have folk dance training (although, according to the results of the same study, 73,9 \% of the respondents would like to go through a process of initial and continuous training in this field), we can be sure not only that the activities that include folk dance in nowadays Romanian primary schools cannot make use of the true educational potential this folklore category has, but that they are, in most situations, educational contexts in which the learners receive erroneous information.

Of course, the discussion could also continue with the added perspective of the causes of this lack of training, as the initial training of the teacher could be made to include courses in the field of folk choreography (by virtue of university autonomy), or their continuous formation could be assured by institutions like the Teaching-Staff Resource Centre. The small number of specialists who have competencies for training in the field of folk dance might be one of the causes, and I believe that this should be looked into by the Romanian higher education choreography institutions, as well as the institutions that study and handle folklore archives. 


\section{The syncretism of folk dance contents}

Folk dance is a syncretic creation, the contents of which reflect all of the other forms of traditional art: musical folklore (through the melodies and songs that accompany the evolution of some dances), literary folklore (through the specific dance shout, orations, or the interpreting of texts in the context of some folk dance situations), traditional arts and crafts (through the props that are necessary in some dances: masks, household items, weapons, weavings, plaits, etc., as well as the traditional costume that is used in the folk dance of each region).

In general, the theoretical approach to folk dance is done on two levels:

a) The level of the contexts in which this folkloric genre appears, the focus being especially on the relation between dance contexts and the functions dance has in each of these contexts. This is a level on which scientific research has yet to produce results that can be the object of didactic transposition, and, as such, this approach will not be used in the present article.

b) The level of contents of folk dance, focusing on the componence, structure, and forms of stylistic rapports between these contents. Because this level offers the possibility of distinguishing scientific content that can be of interest for the field of education, this is the perspective we will use from this point on. The contents of folk dance can be classified as:

1) Kinetic contents. The most important kinetic contents of folk dances are: a) The form of ensemble - referring to the gender componence and the way the group of dancers is organized in the space during the performance of the dance. b) General movement - referring to the way in which the group of dancers (or its subgroups) use space during the dance. As an example, here is the description of the Ardeal dance De-nceput (For the beginning): “The form of ensemble: dance componence - mixed genders; display of formation: alternating - pairs in line, in circle, free; arm position: alternating - the dancers stand facing each other, they hold each other's shoulders, hands, or free. General movement: the movement in space is done in a circle, clockwise, alternating." (Dejeu, 2000). c)

Kinetic structure - it is the most consistent category of contents of a folk dance. The individual's relation to the group and their dance partner, the evolution of the dance in relation to the space, the succession of moves and their relation to music, the significance of moves in relation to the function of dance, the aspects related to the communication of messages through dance, these are all based on the movement elements the folk dance consists of. Given the fact that folk dance encompasses all of the ways in which a human body can usually move, its kinetic structures have invariably been the ones to be studied in ethnochoreologic researches. The diversity of the results of these researches required further detailed analyses, which could not be done without graphic notations of movement elements. This was the reason for which the research of folk dance has practically been forced to use articulated graphic symbols in systems of graphic movement notation. Nowadays, in Romania, there are two notation systems in use: the one developed at the Constantin Brăiloiu Ethnography and Folklore Institute, and the one elaborated by Teodor Vasilescu 
and Sever Tita at the National Centre of Traditional Creation. Recently, there have been researches in folk dance transcribed in the Laban notation system, thus making use of the advantages this system presents in offering a complete, detailed, and suggestive graphic representation of the kinetic-temporal aspects specific to folk dance.

In the structural analysis of folk dance, movement elements are organized in the following hierarchy (Andrei Bucșan, 1965): a) The choreographic element - it is the simplest movement element. A choreographic element is not distinctly present, but it is distinguished on a theoretical level for the study of the fusion it organically makes with the other choreographic elements in the context of movement groups. An example of choreographic element is jumping once on one foot.

b) The choreographic cell (or the kinetic cell) - it is the first movement unit encountered in a dance, which can have, in certain situations, some degree of independence. The choreographic cell is a small kinetic entity, without "its own artistic meaning”, that is made of two, or three choreographic elements, grouped around a main accent. The choreographic cell has a kinetic theme in its content.

c) The kinetic motif - it is the smallest movement entity with its own artistic meaning. The construction of the kinetic motif is well-defined, movements have fixed relations, and they usually contain two main accents. Kinetic motifs are structural entities that, through procedures of choreography construction, determine the form of larger choreographic entities - the choreographic figure, or the choreographic phrase, respectively. They are also the ones to assure the premises for the interpretation of the dance movement in a certain stylistic and expressive manner. Starting from this, ethnochoreologic research has given special attention to identifying the criteria on which movement is organized, and there is distinction being given to kinetic motifs, in their relation to each other. The most often used criterion in this regard is that of the kinetic theme included in the motif's cells. Thus, the classification of kinetic motifs in Romanian folk dance presents 9 distinct categories of kinetic motifs, and in each one of these there is one, or, at most, two types of kinetic themes, which have a similar form (according to Bucșan, 1965):

(1) Accommodation (simple, passing) motifs (symbol A) that contain the kinetic themes of Walking (symbol A') and/or Simple steps in place (symbol A");

(2) Motifs with foot kicks (B), which comprise the kinetic themes Stamping on the ground (B') and/or Heel-stamping (B”);

(3) Motifs with hooks (crossed steps) (C), which encompass the kinetic themes of Frontward crossed steps (hooks) (C') and/or Backward crossed steps (hooks) (C”);

(4) Spinning motifs (symbol V), made of the kinetic themes Actual spins (V') and under the hand spins (V");

(5) Motifs with hand slaps (symbol P), which consist of the kinetic themes of Slapping hand on foot (P') and/or Other slaps (P”); 
(6) Motifs with independent hand movements (symbol M), which consist of the kinetic themes Rising, lowering the hands (M') and/or Flexions, rotations of the hands (M");

(7) Motifs with torso movements (T), which consist of the kinetic themes Rising, lowering the torso ( $\mathrm{T}^{\prime}$ ) and/or Flexions, rotations of the torso ( $\left.\mathrm{T}^{\prime \prime}\right)$;

(8) Motifs with different utensils (U), consisting of the kinetic themes Handling weapons (U') and/or Handling other objects (U”);

(9) Special combined motifs (S), which encompass the kinetic themes Acrobatics (including jumps) (S') and/or Imitation moves (S”).

At the immediate upper level of organization, kinetic motives generate d) the choreographic figure - the most important entity from the perspective of artistic expression. It is not just a succession of kinetic motifs, but "an entity that is superior in terms of quality, the expression of a well-structured content of ideas" (Dejeu, 2000, p.38). On the last level of kinetic organization of folk dance, there is e) the choreographic sequence (or choreographic strophe); it is an ample construction, which is usually made of two, or more choreographic figures (however, there are situations when the construction of the choreographic sequence is based on the repetition of a single figure).

\section{2) Rhythmic contents}

The kinetic contents of folk dance evolve on specific rhythmic supports, which are also an important category of scientific contents that this folklore category might offer in a possible process of didactic transposition. The rhythms of folk dances are diverse, they contain both simple formulas (binary, for instance), and complex formulas, some of them being rather hard to identify or replicate without a developed rhythmic sense (syncopated-hemiolic, for instance). In terms of metrics, there is no other choreographic genre with such a great variety of rhythmic measure as folk dance. It frequently offers situations in which various kinetic motifs cover the following rhythmic measures: $2 / 4$ (e.g.: most of the dances in the category Hora), 3/4 (e.g.: Polka in Andrieşeni, Iaşi county), 4/4 (e.g.: Românește în ponturi/ Romanian in Jests, from Ceanu Mic, Cluj county), 5/4, 6/4, 6/8 (e.g: Țânțărașul/ The Little Spider, from Deleni, Iași county), 4/8 (e.g.: Bătrânescul cu bățt The Old One with a Stick, from Cerghit, Mureș county), 5/8 (e.g.: certain motifs from dances like Purtata/ The Wearing, Învârtita/ The Spinner, Șchioapa/ The Cripple, from southern Transylvania), 7/8 (ex. Brâul lui Snop/ Sheaf Girdle - a dance from Banat, Geamparaua/ The Castanet - a dance from Dobrogea), 8/8 (e.g.: Brâu ardelenesc/ Ardeal Girdle, from Făgăraș), 9/8 (e.g.: Românește bătrânește/ The old Romanian Way, from Bunești, Cluj county), 10/8 (e.g: Purtata cu două fete/ The Wearing with Two Girls, Cerghit, Mureș county), 11/8 (e.g: some of the kinetic motifs in the dance Românește în ponturi/ Romanian in Jests, Frata, Cluj county), 7/16 (e.g: Pe-un picior/ On One Foot, Covăsânț, Arad county), 9/16 (e.g.: some kinetic motifs from the Ardeal dance Șiragul/ The String), 10/16 (e.g.:, Mureșana/ The One from Mureş, Poșaga, Alba county), 11/16 (e.g: De-a lungu/ All along, Monor, Bistrița Năsăud county). 
Another important element is caused by the fact that, in the rhythms of traditional dances, there often appear special constructions, in the form of triplets - the exceptional division in which two beats are replaced by three. For instance:

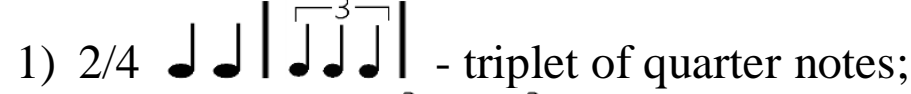

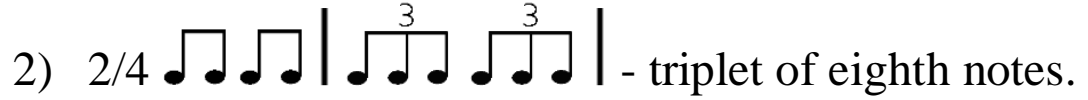

\section{3) Musical contents}

An important part of the scientific contents of folk dances belong to the domain of music and are comprised of the melodies which accompany the dance. Each folk dance has its specific melody, so the great variety of traditional dances corresponds to a great variety of dancing melodies. There is an indestructible relation between the interpreter of folk dances and the melody they dance to, which is caused by that element which movement and music have in common, and that is rhythm. Moreover, the style in which the dance moves are performed is in an interdependent relation with the manner in which the melody is performed. The music is of such a great importance for traditional Romanian dances, that in the cases where the choreography could not benefit from a musical support assured by musical instruments, this was created by the dancer, who would sing while dancing. It is the case of traditional dances that are accompanied by vocal singing, traditional choreographic forms that are still performed in some areas in Transylvania. Among them, there are: Roata femeilor/ The Women's Wheel, from Bogdan-Vodă, Maramureș county, Cătinel/ Slowly from Tăuni, Alba county, Purtata fetelor/ The Girls' Wearing, from Roșia de Secaş, Alba county (Dejeu, 2000, p. 65). However, there are far older writings on dancing with vocal singing support; in the last part of the $18^{\text {th }}$ century, Samuil Micu wrote in his book Scurtă cunoștință a istorii/ Brief Knowledge on the History of the Romanian People (1792 - 1796): "When the Romans danced, they shouted and sang carmines or lyrics; this is what the Romanians do too when they dance.” (Samuil Micu, apud Silvia Ciubotaru, 1984, p. XI, our translation).

\section{4) Literary contents - shouts}

The contents of folk dances that encompass the literary texts which accompany the dances - in short, shouts - are a consistent resource which can particularly support aesthetical and moral education, through didactic transposition. Regarding this aspect, Silvia Ciubotaru states in Strigături din Moldova - Caietele arhivei de folclor nr. IV/ Moldavian Shouts - Folklore Archives, no.4: "The shout, a species that has significant value in Romanian folklore, has not received too much attention from the specialists, and it is often treated even with slight condescendence... The shout has mostly caught the attention of literates, rather than folklorists, and it is an excellent sample of the Romanian peasant's wittiness, high ethics, and humour" (Silvia Ciubotaru, 1984, p. I). This last statement reflects the shout's attributes that allow didactic transposition even in the context of removing it from the interpretative context 
of dance. Seen from inside traditional dance, from the dancer's perspective, the shout is a stylistic element that characterizes the affective manifestation of its interpretation. Furthermore, the shout is a channel for the dancer's verbal communication with their partner, the group of dancers, and sometimes even with the people who are not part of this group, but who are present in the designated space of the interpretative context of dance.

\section{5) Contents that refer to individuals - informers on traditional dance}

The informer on folk dance is the individual who lives in, or has direct ties with the rural community the dance comes from, they are an interpreter of local folk dances who has the community's recognition and who can interpret dances, in order for them to be recorded or noted graphically, and can offer added information on them, in the conditions of field data collection. Similar to other folklore preservers, some of the informers on folk dance, bearers of valuable elements of immaterial traditional patrimony, can receive national recognition and be granted the honorific title of living human treasure, a UNESCO initiative that is regulated in Romania through the Order of the Ministry of Culture no. 2941 from 27/11/2009. References to the folk dance informer's name, age, social status, occupation, professional or occupational paths, family ties etc. are in themselves categories of content that are especially important from the perspective of the socio-cultural context in which folk dance appeared and evolved. Also, some of the physical and psychological particularities of the informer on folk dance can offer valuable content elements from an anthropological perspective.

\section{6) Contents regarding folk dance terminology}

Each folk dance bears a name. The great variety of dances in Romanian folklore (according to Bucșan, 1971, p. 35, the average number of dances identified in folkloric areas can be, in regions like Oltenia, anywhere between 30 and 40) has generated a great variety of names, which has raised the interest of Linguistics specialists towards folk choreography. Recent studies in folk dance terminology have proven, for instance, that, on the level of etymology, a great number of terms (dance names) come from Latin, Slavic, Hungarian, Greek, or are of unknown origins, and that many of the names of traditional dances are directly connected to: (a) the kinetics of the dance - for instance, the dances: Bătaia/ The Beating, Bătuta/ The Beaten, Cotita/ The Veering, Intoarsa/ The Turning, Hodoroaga/ The Noisy, Mărunțical The Small-Stepped, Salta/ The Jumping, Săltuța/ The Little Jump, Tropotita/ The Tramping etc.; (b) categories of individuals who are representative for the community - for example, the dances: A miresiil Of the Bride, A mutuluil Of the Mute, Arnăutul/ Of the Albanian Soldier, Armeneascal Of the Armenian, A socăciței/ Of the Cook, Bărbătescu/ Of the Man, Bătrâneasca/ Of the Elders, Haiduceasca/ Of the Outlaw, Miresecul/ Of the Groom, Nășeasca/ Of the Godparents etc.; (c) a specific geographic space - examples: Abrudeancal From Abrud, Almăjanal From Almaj, Bihoreanca/ From Bihor, Bârnoveanca/ From Bârnova, Breaza/ From Breaza, also known as Ca la Breaza/ As in Breaza, Hațeganal From Haţeg, Slănicul/ From Slănic etc.; (d) names of plants/fruits/vegetables - 
examples: Alămâia/ Lemon, Alunelul/ Little Hazel, Arțărașul/ Little Maple , Busuiocul/ The Basil, Brustureanca/ The Burdock, Chiperul/ The Pepper, Crăițele/ Marigolds, Leușteanca/ Lovage, Pătrunjelul/ The Parsley, Usturoiul/ The Garlic etc.; household items - for instance: Ațical The Thread, Ceasornicul/ The Clock, Dirindeaual The Spin, Mușamaual The Oilcloth, Polobocul/ The Barrel, Sfredeleșul/ The Drill, Țepușul/ The Stake; (e) names of musical instruments - for example: Cimpoiasca/ The Windbag, Cobuzul/ The Pipe, Fluierașul/ The Fife, Geamparaua/ The Castanet; (f) the culinary domain, for instance: Alivencile/ The Pies, Colacul/ The Braid, Palanețul-Doiului/ The Cheese Bread, Piperiu/ Spiced, Pogacea/ Crackling Bread etc.; (g) clothing and accessories - for instance: Brâul/ The Girdle, Băsmăluțal The Headcover, Cațaveica/ The Jacket, Ciubotăreasca/ The Boots, Ciupica/ The Woollen Shoe, Cununal The Wreath, Cușmulița/ The Little Cap, Fustanele/ The Skirts, Marama/ The Headdress, Tundra/ The Greatcoat etc.; (h) names of animals, like: Ariciul/ The Hedgehog, Capra/ The Goat, Căiuțiil The Horses, Călușarii/ The Horse Riders, Cățaua/ The Bitch, Ciocănița/ The Field Mouse, Găina/ The Hen, Hulubașul/ The Little Pigeon, Murgulețul/ The Little Dun Horse, Rața/ The Duck, Ursul/ The Bear etc.; (i) names of people - examples: Anicuța, Catincuța, Ghiță Cătăniță, Haiduc Butea, Jianu, Leana, Marițica, Sârba lui Tache, Sârba lui Moacă, Smărăndica etc. (Bolotă, 2011).

Alongside the aforementioned contents, folk dance also provides information on: traditional costume (chromatics, cut, ornaments and their meanings), traditional crafts (through the props that are used in some dances), several rites and traditions that assure the expression contexts of folk dance etc.

\section{7) Style - the quintessence of folk dance contents}

The aforementioned contents interact in various forms, intensities and degrees, thus determining, for each folk dance, an essential, defining element in terms of interpretation, which is called style. Because folk choreography is a syncretic creation that is directly and permanently influenced by the context of its manifestation, by "style of folk dance" we must understand more than the manner in which the dance is performed. Although there still are strong disagreements in regard to the perspective from which the style of folk dance should be approached, Ethnochoreology offers a model of analysis for the intension of this concept that, although rudimentary, can be useful in the educational application of folk choreography. Starting from the level of the choreographic figure in the kinetic organization of dance movement, we enter the interpretative area of folk dance on which it is strongly influenced by the psychomotor particularities of the individual and the group they are part of. The most visible elements of dance movement on this level are a reflection of the way in which the dancer and/or the group of dancers: (a) apply in interpretation their kinetic-rhythmical knowledge, (b) relate to the available dance space, (c) assure the dynamics and various degrees of intensity of movement, (d) give plastic quality and expressive forms of interpretation to dance movement, (d) emotionally support the dance in its entire duration. A basic understanding of 
the style in which a certain folk dance is performed can begin from answering the following three questions:

(1) Which are the elements of folk dance to which the individual, or the group can apply different interpretative options? (one mustn't forget that folk dance is a collective creation in which the members of a community use contents and stable forms of movement that are representative for them in a given sociocultural and historical context, and which they pass on to their descendants by word of mouth),

(2) Which are those interpretative options? and

(3) What are the limits of their variations when the dance is interpreted freely and respects its function for the group?

Referencing the conclusions they reached after having studied an important repertoire of traditional Romanian dances, the specialists at the C. Brăiloiu Ethnology and Folklore Institute tried to answer these questions, using a model of analysis of the style of folk dance that comprises 6 categories of elements: 1) The general movement of the group - described by the space needed for the performance of the dance and by the tempo of performance, 2) The individuals' footwork - in regard to force, amplitude, and the height of the dance steps, 3) The movement of other parts of the body - arms, head, torso, 4) The interpretative variety inside the group - with the following components: interpretative variety between dancers of the same gender, interpretative variety between genders, interpretative variety between age categories, 5) Emotional extraversion - regarding the participation through gestures, mobility of physiognomy and the interpretation of cries and shouts, 6) Dynamics - regarded as a measure for the intensity of movement (E. Balaci, 1964). Ethnochoreologist Andrei Bucşan has made this stylistic analysis model operational, applying it on a choreography repertoire collected from 330 Romanian rural settlements, and he proposed values, intervals, and hierarchies for each category of stylistic elements (Bucșan, 1971). The results of this analysis have led to the creation of a map of Romanian folk choreography, which consists of four choreographic dialects (Danubian, Western, Carpathian, and Macedo-Romanian), and many "aberrant, intermediary areas", as the author calls them (idem pp. 51 - 69). Although we do not fully agree with the division of the territory of Romanian folklore put forth by Andrei Bucşan (especially since subsequent research has proven the inaccuracies of his stylistic map), we notice the model used by the author and the fact that his work included indicators that have remained valid.

All of the aforementioned elements are scientific contents on the level of which folk choreography includes valid cultural values, which could only by error be considered as pertaining to a retrograde culture. The consistency of these contents in cultural values that can effectively support various types of education, on any level, not only fully justifies the educational attempts to apply folk dance that have happened so far, but it also calls for the initiation of an educational didactic transposition of folk choreography, which, however, must be done coherently and correctly from the perspective of education sciences, as well as from that of Ethnochoreology and Folkloristics. 


\section{Elements that define the educational potential of folk dance}

The interest shown by the Romanian education system towards folk choreography, on the level of both formal education (through including elements of folk dance in several courses that are taught in vocational choreography education), and the non-formal one (especially in primary and secondary education, in children's clubs, or through budgetary allowances for folkloric events), prove an openness of the educational environment toward this folkloric domain, based on the recognition of educational values, which are identified on the level of folk dance contents. However, as we have previously noted, the fragmentary and incoherent approach of this folk genre in schools can have unrepairable negative effects. But schools will go on with their educationalformative processes, and the situation can only be corrected as things unfold. In this regard, a logical step would be for the approach of folk dance in schools to be done from the perspective of theory and curriculum development, this being an up-to-date approach in contemporary pedagogy. However, there is the question whether folk choreography is able to generate a folk dance curriculum. Far from trying to formulate an answer to this question, we will focus on several premises and directions that seem to suggest an affirmative reply.

We will consider that folk dance has an educational potential, as far as its structure contains elements that are of educational value for the current educational process. This aspect is already applied, to some extent, in the Romanian school. However, the educational potential can only be a premise for a folk dance curriculum, if it reaches a level of consistency that reflects an increased ability of the scientific contents of folk dance in supporting complex processes of qualitative and quantitative selection, and of didactic transposition. Looking at these conditions from the perspective of the curriculum (Crețu, 1999, p. 211), we are able to state that, in order to prove consistent educational potential in relation to a possible folk choreography curriculum, folk dance must simultaneously satisfy at least the following conditions:

\section{1) Folk dance must be able to generate consistent and diverse curricular} contents. According to Carmen Creţu's definition, curricular contents "represent a system of values, selected from scientific knowledge, social practices, and the school culture sui generis, that have been acquired by the society up until a moment of reference, and that are didactically transposed in terms of knowledge, abilities, attitudes, and integrated in the preschool/school/university/post-university curriculum" (Crețu, 1999, p.214). From the perspective of this definition, we can say that, in order to generate curricular contents, folk dance must satisfy at least the following three conditions:

(a) Giving pertinent scientific contents to the educational act. This condition aims at the structural-functional dimension of folk choreography which we have referred to previously, and it opens the discussion on the capacity of the contents of folk dance to meet the requirements of pertinence indicators such as those formulated by George Văideanu in Educația la frontiera dintre milenii/ Education at the Turn of the Millenium (Văideanu, 1988, pp. 188 - 190). A 
general reference to these indicators generates aspects of the type that we shall present further on, which can constitute the foundation of a future direction in the research and analysis of folk choreography.

The syncretism of the contents of folk dance open the possibility of new approaches to the art forms it includes. For instance, the modern methods of graphic notation of dance movement (dance notation systems), which are constantly being used in Ethnochoreology and applied through manifold publications on folk dance, facilitate computer use in the collection of dances, the creation of folk choreography databases, the study and application of elements from existing databases. It is worth mentioning that these notation systems consist of graphic symbols of movement elements that are distinguished in regard to rhythmical values, as well as the rules for organizing these symbols in order to suggestively and faithfully express the movement that is being noted. As a component of folklore, folk dance comprises values that are specific to this domain. The coherent approach of these cultural values in an educational context can be a useful step towards satisfying the educational need for knowledge of cultural heritage and traditions, a need that is constantly being expressed on all levels of education.

In Romanian folk choreography, the main function of dance is that of relation, as it becomes a means of communication for the participants. There is a special quality of communication during the dance, as, on the one hand, it is done in a context in which norms are easily accepted, because they are the result of a collective creation based on moral and aesthetic values specific to folklore, and, on the other hand, communication is done with the help of meanings given to gestures and expressive moves that make use of the psychomotor, character, and personality traits of the individual that are considered valuable and representative for the community. Folk dance is an activity that is already being done in educational contexts, through formal or non-formal interdisciplinary activities, it presents relevant premises for constituting a folk dance curriculum, adapted to types of education, but it is also a form of social and cultural expression. After all, I believe that there are few people who have never been in the situation of expressing themselves through folk dance, or, on the contrary, of regretting that they "don't know and can't" dance in this manner. It is hard to question the usefulness of the ability to perform a folk dance, especially today, when the need for physical movement is doubled by a renewed attention to traditional cultural values, as an answer to the need for knowledge of heritage and traditions, a common need in schools, communities, and many families.

Folk dance requires that its interpreter has a high level of cognitive, affective, and psychomotor involvement. First of all, folk dance calls for the learning of several precise elements of dance movements, then passing these elements through the filter of the interpreter's personality, the demarcation of the inner space of structural variability, and, finally, the expression of different states, emotions, and messages through assumed dance movement, conditioned by the available physical qualities and motor skills. The consistency and diversity of the contents of folk dance and the interdisciplinary opportunities 
they create mean that the educational approach to folk dance can assure a balance between theoretical and practical elements, given that these contents are coherently and correctly transposed in regard to the stylistic aspect.

The results of ethnochoreologic research have allowed various morphological, typological, functional, etc. demarcations and classifications of folk dances, in which there are applied criteria that derive from didactic principles, among them, the criteria that refer to the ontogenetic development of the individual. This allows for the coherent organization of the contents of folk dance, in terms of a dance curriculum, supporting other types of education in an interdisciplinary way. Folk dance is an activity that is based on movement and interactivity, and it allows for the organization of learning experiences both in schools and outside, in the community. This aspect makes activities which include folk dance valuable from an educational perspective and especially attractive for the students, under the condition that they are properly developed.

Although there are, in Romania, institutions that are specialized in the preservation, promotion, and application of folk choreography, including in the form of performances, the training of the specialists in this field is not done through clear higher education programs. Things do not look well in primary or secondary education, either: choreography students do not have a school program for the courses that approach folk dance, as most of it is left for the teacher to decide upon and dependent on their competencies in folk dance, competencies that weren't acquired through a coherent initial or continuous training, as we have previously mentioned. This is probably the most important reason why the institutions with activities in the research and application of folk dance should make use of the interest in folk choreography shown by schools, and the specialists in these institutions could give the decision-makers in educational policies the motivational-scientific support for the joint initiation and implementation of a folk dance curriculum, differentiated and adapted to each category and level of education.

(b) Satisfying all of the categories of arguments that can justify their selection as part of the processes of didactic transposition. According to Crețu (1999, pp. 215 - 218), the selection of contents is made considering the following types of arguments, to which contents of folk choreography can relate in the following way:

(b.1) Theoretical arguments:

(1) Scientific: The existence of scientific researches in the field of folk choreography and the interest of schools in their outcomes prove the existence of scientific arguments for using certain contents of folk choreography in educational activities, even though, unfortunately, these only aim at the aspects that relate to the performance-type application of dance. Folk dance is less used in interdisciplinary approaches, but not because of its lack of potential in this regard, but, on the one hand, because of the low interest on behalf of folklorists in disseminating the results of their researches in forms that could be useful for the process of didactic transposition, and, on the other, because of the teachers' precarious training in the field of folk choreography. 
(2) Developmental psychology: The typological, morphological, functional, etc. classifications done by Ethnochoreology on the level of folk dance point at criteria relating to the individuals' ontogenetic development and individual psycho-behavioural traits. Thus, for the very young, there is the so-called children's folklore - a folklore genre which encompasses forms of traditional dance corresponding to this age, and, on the opposite side, for the elders, there is the category of elderly dances. Between these margins, there are types and categories of folk dance that reflect and make use of the particularities of every phase of ontogenetic development of the human being. From a different perspective, Romanian folk choreography also presents functional categories that showcase the interpreter's physical and psychomotor qualities, such as exhibition dances.

(3) Psychology of learning: In adequate learning contexts, the syncretism of the contents of folk dance (which are based on the individual's cognitive, affective, and psychomotor involvement in the interpretative act) can be an important support in the stimulation of the learner's perceptive learning (in the cognitive and behavioural aspects aimed by this type of learning) and motor learning, which aims at goals that are specific to the interpretative act.

(4) Pedagogic: The contents of folk dance can generate learning experiences, on pedagogic grounds that aim at (Crețu, 1999, p.216): (a) Assuring the unity of curricular contents and several educational purposes, goals, and objectives (for instance, those that are decided in the area of artistic and vocational education), (b) Assuring the unity and continuity of general and specialized culture; kinetic contents, rhythmical-musical contents, the associated literary text, as well as those that refer to terminology, can equally be the objects of educational activities of general culture, as well as specialized scientific research.

(b.2) National educational policy arguments. An attempt at didactic transposition of folk dances that are representative for the Romanian folk choreography repertoire can also be motivated with national educational policy arguments, if there are taken into consideration at least the following aspects:

(a) Folk dance can support the development of social and civil competencies, and of sensitisation and cultural expression competencies, which are keycompetencies in The Law of National Education (Law 1/2011);

(b) The functions of the school institution, especially the socio-human, the cultural, and the educational ones, expressed on the individual, institutional, community, and societal levels, can be strongly supported by educational activities in the field of folk choreography.

(c) The disciplines Music and movement, and respectively Rhythm and movement for the primary education cycle, can apply, through their contents, some of the elements of folk dance, which, in turn, could significantly support the educational objectives of these disciplines.

(b.3) Personal arguments (decided by the teacher). In the current conditions, in which folk dance is not a significant part of the sphere of interests of formal education (an exception being the specialization in choreography, in vocational artistic education), and the free form of manifestation of this type of traditional 
art is in an accentuated qualitative and quantitative regression, the teacher's personal arguments play a massive part in their decision to be involved, along with their students, in educational activities that include traditional dance. Given that "the selection and organization of contents for the didactic process depend on... the teachers' preferences, their idea of culture assumed on a pedagogical level, their competencies, attitudes, didactic style, as well as the psychobehavioural particularities of the group of students" (Crețu, 1999, p. 218), the teacher's personal arguments regarding folk dance are of utmost importance, if we are to take into account the fact that in the educational environment there is an increased interest, on behalf of the schools, in initiating outside-the- school and extracurricular activities, which are coordinated by teachers, as well as an interest in allocating important resources for supporting these activities: there are school festivities, local, regional, national, and even international festivals being organized, there is financial support for national and international projects with the theme of traditional dance, or for the organization, endowment, and proper functioning of children's folk ensembles, etc. A study on teacher motivation for involving in this type of activities, as well as on the effects of the teacher's motivational state on the quality of the educational act done through this type of activities, would be of interest for the educational environment, and not only it.

(c) For the purpose of didactic transposition, the contents of folk dance must allow for their organization according to principles that have didactic rationality and that assure that the defining stylistic particularities are respected. The types of organization of contents that are frequently used in the teaching of folk dance are:

(1) Linear organization, using:

(1.1) the criterion of the kinetic theme, in the following order: accommodation motifs (symbol A) - motifs with foot kicks (B) - motifs with hooks (C) - motifs with spins $(\mathrm{V})$ - motifs with hand slaps $(\mathrm{P})$ - motifs with independent manual moves (symbol $\mathrm{M})$ - motifs with torso movement $(\mathrm{T})$ - motifs with different utensils (U) - special combined motifs (S),

(1.2) the criterion of the form of ensemble, in the following order: free dance group dance - dancing in pairs - solo dance. (2) Concentric organization, which results from successively applying the criterion of the form of ensemble to each category aimed at by the criterion of the kinetic theme.

(3) Concentric organization, using the criterion of the rhythmic support of dance, in the following order: dances performed to binary/ternary/quaternary syncopated - asymmetrical (binary/ternary/quaternary) - syncopated hemiolic rhythms.

(4) Spiral organization, reached through the combination of types of concentric organization with various linearities, the most often used (and the most useful for the preservation of the folk choreography genre) being the approach to contents from a rhythmical perspective on several linearities, which result from the stylistic organization of kinetic elements of dance and the adjacent literary contents. We mention that Romanian folk choreography offers sufficient dances 
for the quantitative and qualitative organization of contents in the ways that have been presented.

2) Folk dance must generate fields in which one can delineate educational objectives with different degrees of generality: general objectives that are formulated in agreement with the purposes and goals of education, medium (specific) objectives that aim at modifying the learner's cognitive, affective, and psychomotor behaviours (Landsheere \& Landsheere, 1979, p.24), as well as operational objectives, through which it is possible to identify educational tasks that are specific to folk dance, and which ca be appropriately explained through words (Cucoș 2006, p.198), making use of the representative elements of choreographic and folkloric vocabulary.

If by the area of an objective we understand "the entirety of real situations (and not exercises) in which competency is useful" (Landsheere \& Landsheere, 1979, p.52), and by competency, "a combination of knowledge, anilities, and attitudes, applied in controlled situations, in order to obtain visible results" (Bocoș and co. 2015, in Sava coord., 2015), then the existence of an area of educational objectives belonging to the field of folk choreography is assured by the situations in which a competency in folk choreography can prove to be useful. These situations do exist, and they can be classified in three categories: (a) interpretative situations that require competencies in interpreting folk dance; these situations refer to folk dance as a means of communication, as an organized form of spending leisure time as a member of a folkloric ensemble, and as a profession practiced as a member of professional folkloric ensembles; (b) situations of teaching-learning dance in different formal and non-formal educational contexts, on the level of initial or continuous training, etc., that are based on pedagogic competencies in the field of folk choreography, and (c) situations that aim at the study of the contexts and forms of folk dance, which require research competencies, adapted to the field of folk choreography.

From the perspective of educational purposes, the educational approach to folk dance can support the learner in acquiring at least two key-competencies (mentioned above), and this serves in justifying the formulation of educational objectives that aim at the scientific contents of folk dance. The syncretism of the contents of folk dance, as well as the stylistic and functional particularities that organize this folklore category in a specific way, allow for educational approaches, and, implicitly, the formulation of objectives, with a high level of specificity, in all of the three behavioural domains that are of interest for the pedagogical act: the cognitive, affective, and psychomotor domain. The stylistic particularities of each folk dance, as well as the existence of several models of analysis that emphasize particularities on the basis of which there have been distinguished several typologies in the national repertoire of folk dance, enable the formulation of operational educational objectives in the field of folk dance. All of these categories of objectives aim at the learner's acquiring of competency in folk dance, which proves to be useful, as we have previously stated, in several social life situations (such as leisure time, or professional activities). 


\section{3) The teaching-learning of folk dance must be done in agreement with}

didactic principles. Folk dance has a predisposition in relation to didactic principles, which is mainly determined by its functional and structural principles. The existence of various situations in which competencies in folk dance can be applied (which we have previously mentioned), as well as the fact that the acquiring of knowledge and abilities in folk dance can be, and frequently are, applied in interdisciplinary education contexts (which is determined by the syncretic nature of the forms of folk dance and the way they are stylistically organized), represent arguments to support the statement that the educational approach of folk dance respects the didactic principle of integrating theory and practice.

The diversity of forms of folk choreography we can find in the segment children's folklore - elderly dances, as well as the existence of an intrinsic affective component of every stylistic content of folk dance, are aspects that, under the conditions of a correct approach of folk dance from an educational and ethnochoreologic perspective, call for the selection of contents on criteria that take into account the learner's psyche, in the sense of respecting their individual psychological particularities. Which means that educational activities in folk dance cannot reach their objectives unless they are subordinate to the didactic principle of respecting age and individual particularities. In other words, the consistency of the forms of folk choreography in the aforementioned segment allows for a dimensioning of the selected contents that will also take into account the learner's psychological age and individual particularities, which is in agreement with another principle, that appears as a "consequence" of the one we mentioned above (Cucoss, 2006. p.354), and that is the principles of accessibility of knowledge, abilities, and skills.

In regard to the principle of systemization and continuity of learning, it essentially refers to the exigency that, in the teaching process, the contents being transmitted are organized and projected in such a way, that they are a logical continuity of the ones that have already been learnt, integrating systemically, and assuring a progressive evolution of learning. This principle aims at two aspects: the systemizing of knowledges and the assurance of continuity in the teaching-learning process. From a psychological perspective, systemizing and continuity are based on the principle of (specific and nonspecific) transfer, and on the achievement of an intra- and interdisciplinary connection (I. Nicola, 1996, pp. 355-356). Systemizing refers to the requirement that the entire content that is being projected and transmitted to the students is organized in a system, and that it assures the proper conditions for its integration in the system of the students' previous acquirements. In primary and secondary education, systemizing the contents of folk dance can be regarded from two perspectives: (1) the correlations with other disciplines, which highlights (1.1) the correlation between kinetic contents (kinetic themes and motifs, display formations, etc.) and the competencies aimed at through Physical Education, (1.2) the correlation between rhythmical contents, or some of the contents of affective participation (joining the interpretation of the dance with melodic vocal self-accompaniment), 
and Musical Education, (1.3) the connection between the contents of the literary text that is adjacent to traditional dance (the shout), or the terminology of traditional dances, and the discipline Romanian Language and Communication, (1.4) the correlation between the contents that are adjacent to dances (information on the area they come from, informers, occasions for dancing, typological arguments, etc.) and contents of disciplines like: Geography, History, Civic Education, etc. These correlations can be intradisciplinary, interdisciplinary, or integrated to a discipline.

(2) From the perspective of the consistency of the contents and the logic of constituting a distinct discipline, folk dance can be organized as a distinct discipline, in at least three different variants: (1) starting from its kinetic contents - ordering the content elements can be done using the logic specific to Physical Education, (2) starting from its rhythmical contents - ordering the content elements can follow the purposes of musical education, (3) starting from the stylistic classification of folk dance - ordering the contents can be done in relation to the geographical element represented by distinct stylistic categories. Although there can also be found arguments for other variants of organizing contents in a prospective distinct discipline, the variants that we have mentioned are the ones that are most often discussed by specialists in folk choreography who do successful non-formal activities with youth and children in the field of traditional dance. In a possible course on traditional dance, the most useful ways to organize contents would be the linear, concentric, and spiral forms, as we have previously described them.

Continuity is a natural consequence of the conditions of systemizing, highlighting the logical articulation of contents assimilated in different stage. In the teaching-learning process of folk dance, continuity must be assured on two levels: the inner structure of each category of contents, and the relation between contents (which is ruled by the stylistic particularities of the specific dance). In regard to the first level, we give the following examples:

(a) The continuity of rhythmical contents is assured by teaching in the following order: binary, ternary, quaternary rhythms, binary syncopated rhythm, binary asymmetrical rhythm, ternary asymmetrical rhythm, quaternary asymmetrical rhythm, syncopated hemiolic rhythm.

(b) The continuity of kinetic contents can be assured by teaching in the following logical order: (1) kinetic themes - in the following order: simple steps in place, walks, jumps, frontward crossed steps, backward crossed steps, heelstamps, trampling, under the arm spins, arm moves, torso moves, slaps on the feet, other slaps, actual spins, handling utensils and weapons, imitation moves and acrobatics,(2) kinetic motifs: accommodation motifs, motifs with hooks, motifs with beats, motifs with spins, motifs with independent manual moves, moves with different utensils, special combined motifs. In regard to the second level, we give the example of assuring continuity of kinetic-rhythmical contents related to the stylistic categories of dance:

(3.1) Folk dances in the category of Horas, in the following order: (3.1.1) steps that are performed in a binary rhythm, respecting the order: accommodation 
motifs, motifs with hooks, motifs with beats, motifs with spins, (3.1.2) steps performed in binary syncopated rhythm, in the order: motifs with walks, motifs with beats on the ground, motifs with independent manual moves. (3.2) Folk dances in the category Dancing in pairs, in the following order: (3.2.1) steps performed in a binary rhythm, respecting the order: accommodation motifs, motifs with hooks, motifs with beats, motifs with spins, (3.2.2) steps performed in a binary syncopated rhythm, respected the aforementioned order, (3.2.3) steps performed in a syncopated-hemiolic rhythm, respecting parts of the order of kinetic motifs we have previously described. The continuity of learning folk dance can be assured by applying the orders we have presented to the categories of folk dance: Dances for a large group, Dances for mobs, Wearing, Virginal Dances, Girdles. In assuring continuity, there must be special attention given to the local stylistic aspect. Because of this, dances that are at the interference of major styles are only taught after the learner has proper knowledge of the styles in contact.

Another co-ordinating didactic principle of folk dance is the principle of correlation between the sensorial and the rational, the concrete and the abstract (the principle of intuition). This principle derives from the predominance of the concrete character of thought among children, a psychological aspect that imposes on the teaching-learning process the requirement of forming knowledge, basic skills and abilities through the realization of perceptions and representations on the basis of direct contact (visual, auditive, tactile, kinesthetic). In the process of learning, the direct action of stimuli on sensing organs is the basis for sensorial knowledge, which is done with the help of intuition. "For J. A. Comenius, intuition is 'les aurea' (the golden rule) of pedagogy. He recommends that everything is directed at the senses, as much as possible. In order to increase intuition value, it is recommended that teaching starts whit the concrete description, or the intuitive anticipation of the theme." (Palicica, 2002, p. 75). In short, teaching folk dance unfolds in the direction described by the principle of intuition, in the sense that the student must see the movement, identify the rhythm it is done in, hear the music, the shouts, and understand the explanations given by the teacher. On a superior level of intuition, when the learner has already acquired sufficient knowledge and abilities, the noting systems of dances become excellent instruments for the teaching-learning of folk dance. And in the current conditions, with written collections of folk dance being increasingly important information sources, the teacher's intuition and that of the student's have to teach levels that allow them to use these sources.

Regarding the Principle of conscious and active student participation in the activity of teaching, learning, evaluation, the two aspects aimed by this principle - conscious participation and active participation - are sine-qua-non conditions of the educational process of teaching-learning folk dance. In general, conscious participation in the act of learning implies the clear and profound understanding of the contents, avoiding mechanical, formal memorization. Furthermore, the organic connection between the (kinetic, rhythmical, affective, etc.) contents of 
folk dance, as well as the requirements of creative participation in learning a dance (which makes possible the re-creation of some of its dimensions) and of interpreting the dance in a certain style, make the learner consciously participate in the learning process, in the conditions of high levels of intentionality and voluntary effort. Without this attitude on behalf of the student, learning folk dance could not be possible. For this reason, before the beginning of the traditional dance lesson, the teacher must first induce to the student a state that generates an attitude oriented on conscious participation in the educational act that is about to take place. Active student participation leads to the requirement that the assimilation of information, the forming of skills, attitudes, and competencies, are based on student activities that determine the optimal use of thought, intelligence, and the students' other intellectual, motivational-affective, and volitional processes. (Cucoss, 2006 p. 357). An essential element in learning traditional dance is the student's individual study. After the student understands the content they have to assimilate, as well as the stylistic manner in which this content must be interpreted, there follow repeated phases of individual study, under the teacher's supervision. Once again, the stylistic element comes to the forefront, asking for harmonizing the interpretative requirements imposed by the characteristic of the folk dance being studied with the student's abilities, which depend on their corporal-kinesthetic intelligence. The process of teachinglearning folk dance cannot take place without an intense state of active student participation.

Relating the activities of teaching-learning folk dance to the principle of thorough acquiring of knowledge, abilities, and skills, must be done from the perspective of the fact that, in order to achieve the contemporary educational goals, the requirements of this principle impose that education is thorough and lasting (Cucoș, 2006, p. 358). The thoroughness of educational activities in folk dance is assured by the following qualities of its contents: (1) The contents of folk dance give the possibility of coherent and correct dimensioning in relation to the purposes aimed at by the established educational objectives, the number and structure of projected activities, the adaptation of stylistic particularities to the student's psychomotor and affective particularities, etc. (2) They assure repetitions of acquirements: the structural correlations between the elements of contents, as well as the stylistic correlations that exist between the elements of folk dance, assure that, during the interpretation of a dance, there is a repetition of a large volume of acquirements in a short interval of time; (3) New elements can be introduced by connecting them to already-acquired ones (for instance: the introduction of a new kinetic motif for completing a choreographic phrase, or figure; the introduction of a new rhythmical motif for completing the rhythmical formula of the dance, the introduction of the shout for completing the form of stylistic interpretation, establishing the limits of movement for demarcating the area of structural and creative variation in relation with the requirements imposed by the style, etc.); (4) They offer the possibility of concentric organization of teaching for assuring the repetition of previously assimilated elements; (5) They offer the possibility for evaluation and self-evaluation during 
each interpretation. The thoroughness of the educational act must be completed by its lastingness. "Lastingness is conditioned by adhering... to a set of unshakeable values, to explicative standards that work as points of reference not only in critical situations, but also in quotidian manifestations and events" (Cucoss, 2006, p. 358). Folk dance, the component of the folkloric genre that has the greatest addressability in relation to the dimension of human collectiveness, encompasses national cultural values that the modern society and, implicitly, modern school, not only accepts, but also considers a part of the educational need for knowledge and preservation of cultural heritage and traditions. Moreover, the forms of application of knowledge in traditional dance are diverse and up-to-date: from simple dancing occasions that frequently appear un everybody's life, to transdisciplinary/interdisciplinary educational activities, contexts of intercultural dialogue, performances, national or international cultural projects, studies, researches, etc.

The aspects that we have mentioned can be arguments for supporting the idea that, in an educational approach, folk dance has a predisposition to respect the didactic principles which rule this domain, and, furthermore, these principles strengthen the normative aspects which derive from its quality of being a component of folklore.

\section{4) Teaching and learning folk dance must be done through pedagogical methods that lead to the achievement of preestablished educational goals and objectives}

The syncretism of contents of folk dance, transposed in the stylistic particularities of each studied element of folk choreography, generates various operational objectives, in the context of teaching-learning folk dance, for the achievement of which there are diverse didactic methods, adapted to each type of objective. Thus, for achieving the desired changes in the learner's cognitive, affective, and psychomotor behaviours, approaching kinetic-rhythmical, musical, literary contents, functional or adjacent contents of dance (such as the ones that describe the social, cultural, and historical context in which the folk dance appeared and evolved) etc. impose using different methods, some of which are considered classical, others modern, or even innovative. Without considering that these are the only methods that prove to be useful, we state that the methods that best adapt to the teaching-learning of folk dance (and in the absence of which, such a process cannot take place in a correct and coherent manner from the perspective of the sciences of education and Ethnochoreology) are:

(1) Expositive methods, which are used for teaching concepts of folk dance, for the synthesis and transmission of knowledge and artistic creation experiences belonging to folk choreography, for instilling in the group of learners the "contagion" phenomenon (collective suggestion), which is highly important in transposing on an interpretative level some of the stylistic particularities that are defining for the folk dance being studied, etc. Among expositive methods, there are: (a) explanation - used for the enunciation of concepts, definitions, rules, and principles that organize the domain of folk choreography; (b) description - 
which is used for making judgements on the characteristics of the elements of content, or the contexts in which the dance evolves, and (c) symbolic exposition - which has been in use since the appearance of dance notation systems an their application in editing books that contain collections of folk choreography.

(2) Interactive methods (dialogue), based on the existence on behalf of the learners of a significant degree of knowledge in the field of folk dance, which allows the demarcation and understanding of problem-situations that they have to solve. The most frequently used methods in this category are: (a) heuristic conversation - for solving situations relating to dance kinetics, for adapting one's own potential to express to the procedures of construction through dance movement and transmission of preestablished messages, states, and feelings, for situations generated by respecting the stylistic particularities of dance, etc.; (b) problematizing - it requires an advanced level of knowledge and abilities in folk dance and it is especially used in solving interpretative problem-situations that might appear in the process of stage transposition of folk choreography.

(3) Methods of mediated exploration of reality, among which there are: (3.1) the audio-visual technical demonstration - it consists of having the learners watch several video recordings of folk dances that are valuable as educational resources, (3.2) the case study - used both as source of knowledge, and as a practical applicative means (Cerghit, 2006, p.232) for making use of the folk dance resources given by the analysis of social, choreographic, or educational contexts of folk choreography; using this method implies that the learners have advanced knowledge and skills in folk dance on a high level.

(4) Methods based on real practical action - two of which are permanently used: (4.1) Exercising - given that learning folk dance implies that the learner assimilates, for ulterior interpretation, a syncretic complex of cognitive, affective, and psychomotor behaviours, materialized in movements that are structured kinetically, rhythmically, and stylistically (interpretatively) in preestablished forms, taking into account that "the method of learning through exercising means repeatedly performing a movement, action, form of behaviour, until they are mastered, until the formation of habits as reactions, or automatic responses to well-defined situations" (Cerghit, 2006, 245), this method cannot be absent from the teaching-learning process of folk dance. It is highly important that this method is applied such as not to restrict the student's creativity. For this, the teacher must have great knowledge of the stylistic particularities of the folk dance they are teaching, and they must encourage the student to apply in interpretation the various intervals of variability offered by the style of the dance (structural kinetic-rhythmical variabilities related to categories of age and gender, limits of intervals that define aspects of dance spatiality, the variability of expressive and personality traits that express the affective participation required by the style, etc.). The other method in this category is (4.2) Practical work - through which the learners, supervised by their teachers, create, individually or in groups, different pieces of folk choreography, which can be anything from choreographic figures or phrase, to 
sequences in which they make use of certain folk dances, or even artistic products in the form of folkloric performances.

For the teaching-learning of folk dances, there can also be used the following didactic methods: (5) learning through reading - this being done on texts that depict folk dances (moves and all of the other elements are described through words), or on choreographic scales (kinetograms); (6) methods of exploring reality, among which we mention personal reflection - it represents a means of getting to the essence of stylistic meanings of elements of folk choreography, which is needed for their transposition in creative interpretations; (7) methods of exploring reality, such as (7.1) independent observation especially useful in the application of the informational potential of context of folk dance, and (7.2) learning through researching documents and historical artefacts that refer to folk dance, which can be old photographs, manuscripts on dance, painted plates, engravings, sculptures, jewels, etc. All of these methods are used according to the educational objectives, and they are conditioned by the level of knowledge in the filed of folk choreography on behalf of both the teacher, and the students.

\section{5) Effective teaching and learning of elements of folk choreography must be done through experiences that take place in the organized context of institutionalized education.}

Given that folk dance is a syncretic form of contents that, separately, are represented in school courses, an educational process that would aim at the elements of folk choreography could undoubtedly take place through didactic activities that are organized in ways similar to those that already exist in schools: frontal activities, group activities, and individual activities. Moreover, there are certain particularities of folk dance, which derive from its quality of cultural-artistic element with roots in local, regional, and national specifics, that give superior educational valences to its approach through certain types of frontal activities (such as visits, trips, or viewing performances), group activities (such as independent exercises, the student circle, meetings with specialists, competitions, etc.), and even individual activities (independent work and individual study, practical work, library study, etc.). In folk dance, just like in the cases of other categories of content, the lesson is still the most useful and most frequent didactic process.

\section{Conclusions}

In order for folk dance to be applied in the process of education, it is necessary, on the one side, that its educational potential is fully comprehended by teachers and by the decision-makers in educational policies, and, on the other, that there are proper contexts for the initiation and implementation of such a process. Understanding folk dance as a source of scientific content is a complex process that requires theoretical and practical study, as well as the expense of important resources, at least of temporal ones. Given that, on the level of the collectives that created it, folk dance has almost vanished as a free form of social and cultural manifestation, and most of the results of researches 
done by folklorists and ethnochoreologists are stored in archives that can barely be accessed, never to be brought to the attention of the large public, there is a very small possibility that a teacher, or a decision-maker in educational policies, might be willing to invest time and material resources for correct and coherent information in the field of folk dance. This possibility is further limited by the fact that the internet facilitates access to information on adapted forms of folk dance, many of which are falsely presented as informational references of scientific value. In this situation, the real, high interest shown by schools in using folk choreography in the process of education must be doubled by an attempt to facilitate the teachers' access to informational resources on folk dance that are consistent, in terms of quantity, scientifically valid, and easy to use. Folk dance is not a content of an outmoded culture, and the education associated to these contents is not retrograde. If this is fully comprehended by the decisionmakers in educational policies, and especially those who organize higher education in the arts, then folk dance will be able to prove its true educational potential, having been given the chance of academic study.

\section{Bibliography}

1. Balaci, Emanuela, Câteva observații asupra stilului dansului popular românesc, Revista de Etnografie şi Folclor, tom 9, nr. 4-5, pag. 509, Bucureşti, 1964

2. Bocoș, Mușata și colaboratori, Orientări educaționale actuale privind curriculumul centrat pe competențe, în Sava, Simona (coordonator), Perspective pentru cercetare în educație, Editura universitară, București, 2015

3. Bucşan, Andrei, Probleme ale sistemului cinetic în dansul popular românesc, Revista de Etnografie şi Folclor, tom 10, nr. 1, pag. 90, Bucureşti, 1965

4. Bucșan, Andrei, Aspecte funcțional-tematice în dansul românesc, articol apărut în Revista de Etnografie și Folclor tom. 16, București, 1970

5. Bucșan, Andrei, Specificul dansului popular românesc, Editura Academiei Române, București, 1971.

6. Cerghit, Ioan, Metode de învățământ, Editura Polirom, Iași, 2006

7. Ciubotaru, Silvia, Strigături din Moldova - Caietele arhivei de folclor nr IV, Arhiva de folclor al Moldovei și Bucovinei din cadrul Universității "Al. I. Cuza" din Iași, Iași 1984

8. Crețu, Carmen, Teoria Curriculum-ului și Conținuturile Educației - curs, Editura Universității” Al. I. Cuza”, Iași, 1999

9. Crețu, Carmen, Teoria și Metodologie Curriculum-ului, în Pedagogia invățământului primar și preșcolar - Anul I - Semestrul II, Editura Universității "Al. I. Cuza" din Iași, 2015

10. Cucoș, C-tin, Pedagogie, Editura Polirom, Iași, 2006

11. Dejeu, Zamfir, Dansuri tradiționale din Transilvania, Editura Clusium, Cluj-Napoca, 2000

12. Giurchescu, Anca - articolul Cercetarea contextuală a dansurilor populare", Revista de etnografie și folclor, Nr. 15 (1), 1970, București 
13. Giurchescu, Anca, Raportul între modelul folcloric și produsele spectaculare de dans popular, articol în Revista de Etnografie și Folclor, tom 16, nr.5, pp. 369 - 374, 1971

14. Landsheere V. \& Landsheere G, Definirea obiectivelor educației, EDP București, 1979

15. Legea Educației Naţionale nr.1/2011

16. Nicola Ioan, Tratat de pedagogie şcolară, Editura Didactică şi Pedagogică R.A., 1996

17. Palicica, Maria, Prelegeri de psihopedagogie, Editura Orizonturi universitare, Timișoara, 2002

18. Văideanu, George,Educația la frontiera dintre milenii, București, 1998 